\title{
Red blood cell transfusion practice in a Pediatric Intensive Care Unit
}

\section{Prática de transfusão de concentrado de hemácias em Unidade de Terapia Intensiva Pediátrica}

\author{
Cibele Mendes ${ }^{1}$, Dafne Cardoso Bourguignon da Silva ${ }^{2}$, Rodrigo Genaro Arduini ${ }^{2}$, Eduardo Juan Troster ${ }^{3}$
}

\begin{abstract}
Objectives: To describe a population of children that received red blood cell transfusions. Methods: A retrospective observational study carried out at the Pediatric Intensive Care Unit of the Instituto da Criança of Hospital das Clínicas of Faculdade de Medicina of Universidade de São Paulo in 2004, with children that received red blood cell transfusions. Results: Transfusion of red blood cells was performed in $50 \%$ of the patients hospitalized. Median age was 18 months, and the primary motive for admission was respiratory insufficiency (35\%). Underlying disease was present in $84 \%$ of the cases and multiple organ and system dysfunction in $46.2 \%$. The median value of pretransfusion hemoglobin concentration was 7.8 $\mathrm{g} / \mathrm{dL}$. Transfused patients were undergoing some form of therapeutic procedure in $82 \%$ of the cases. Conclusions: Red blood cell transfusions are performed at all ages. Hemoglobin concentration and hematocrit rate are the primary data used to indicate these transfusions. The values of arterial serum lactate and $\mathrm{SvO}_{2}$ were seldom used. Most patients transfused were submitted to some form of therapeutic procedure, and in many cases, transfusions were carried out in patients with multiple organ and system dysfunctions.
\end{abstract}

Keywords: Erythrocyte transfusion; Intensive care units, pediatric; Anemia; Oxygenation; Child; Hemoglobins

\section{RESUMO}

Objetivo: Descrever a população de crianças que recebeu transfusão de glóbulos vermelhos. Métodos: Estudo retrospectivo observacional, realizado no Centro de Terapia Intensiva Pediátrico do Instituto da Criança do Hospital das Clínicas da Faculdade de
Medicina da Universidade de São Paulo, em 2004, com crianças que receberam transfusão de glóbulos vermelhos. Resultados: A transfusão de glóbulos vermelhos foi realizada em $50 \%$ dos pacientes internados. A idade mediana foi de 18 meses e 0 principal motivo de internação foi insuficiência respiratória $(35 \%$ dos casos). Doença de base estava presente em $84 \%$ dos casos e disfunção de múltiplos órgãos e sistemas em $46,2 \%$ dos casos. A mediana da concentração de hemoglobina pré-transfusional foi de $7,8 \mathrm{~g} / \mathrm{dL}$. Os pacientes transfundidos estavam sendo submetidos a algum procedimento terapêutico em $82 \%$ dos casos. Conclusão: São realizadas transfusões de glóbulos vermelhos em todas as idades. A concentração de hemoglobina e a taxa de hematócrito são os principais dados utilizados para a indicação dessas transfusões. 0 lactato sérico arterial e a $\mathrm{SvO}_{2}$ foram pouco utilizados. A maioria dos pacientes transfundidos foi submetida a algum procedimento terapêutico e, em muitos casos, foram realizadas transfusões em pacientes que apresentam disfunção de múltiplos órgãos e sistemas.

Descritores: Transfusão de eritrócitos; Unidades de terapia intensiva pediátrica; Anemia; Oxigenação; Criança; Hemoglobinas

\section{INTRODUCTION}

Anemia is the primary reason for red blood cell (RBC) transfusions, and it is especially prevalent and even expected in critical care settings ${ }^{(1)}$. Up to $50 \%$ of children who are hospitalized in a Pediatric Intensive Care Unit (PICU) receive $\mathrm{RBC}$ transfusions ${ }^{(2)}$. Maintenance of an adequate hemoglobin $(\mathrm{Hb})$ concentration is important to establish adequate oxygen delivery to the tissues.

\footnotetext{
Study carried out at Intensive Care Unit of Instituto da Criança, Hospital das Clínicas, Faculdade de Medicina, Universidade de São Paulo - USP - São Paulo (SP), Brazil.

'Pediatric Intensive Care Unit of Children's Institute of Hospital das Clínicas of Medical College at Universidade de São Paulo - USP - São Paulo (SP), Brazil.

2 Pediatric Oncology Institute of GRAACC, Universidade Federal de São Paulo - UNIFESP - São Paulo (SP), Brazil.

${ }^{3}$ Pediatrics, Hospital Israelita Albert Einstein - HIAE - São Paulo (SP), Brazil; Institute for Treament of Cancer in Children - Children's Institute of Hospital das Clinicas of Medical College at Universidade de São Paulo - USP - São Paulo (SP), Brazil.

Corresponding author: Eduardo Juan Troster - Instituto de Tratamento de Câncer Infantil - Rua Galeano de Almeida, 148 - Pinheiros - CEP 05410-030 - São Paulo (SP), Brasil - Tel.: (11) 3897-3812 e-mail: troster@einstein.br

Received on: Sep, 19, 2010 - Accepted on: Apr, 5, 2011

The authors declare there is no conflict of interest.
} 
Oxygen delivery is determined by $\mathrm{Hb}$ concentration in the blood, oxygen saturation, the rate at which this blood circulates to the tissues, and the efficiency with which the oxygen is "unloaded" from $\mathrm{Hb}$ to the tissues $^{(1,3,4)}$. The central venous oxygen saturation $\left(\mathrm{SvO}_{2}\right)$ is directly related to the oxygen content in blood returning from the tissues. Normally, oxygen delivery is four or five times the oxygen consumption ${ }^{(3)}$. As a matter of fact, $\mathrm{SvO}_{2}$ can be considered an important index of tissue oxygenation. The presence of variability in transfusion practices in intensive care settings shows that the best moment for these transfusions has not yet been identified. Published studies have demonstrated substantial variations in transfusion practices and evidence of unnecessary transfusions ${ }^{(5)}$. Indication for $\mathrm{RBC}$ transfusion based only on $\mathrm{Hb}$ and hematocrit (Hct) should be reviewed, as treatment of anemia in critically ill patients warrants further evaluation.

\section{OBJECTIVE}

This observational study was performed to describe the clinical, hematological, and therapeutic characteristics of children who received RBC transfusions in a PICU, and to describe the variables utilized for the indication of these transfusions.

\section{METHODS}

\section{Study design and study population}

Instituto da Criança Pedro de Alcântara is a 135bed high-complexity pediatric hospital affiliated with the Universidade de São Paulo (USP). Its PICU had 13 beds at the time of the study, and does not admit patients in cardiac postoperative state or neonatal period as there are other intensive care units specifically for those children. A retrospective observational study in this PICU was performed, with children who were admitted from March 1st 2004 to September $1^{\text {st }}, 2004$, and received RBC transfusions. Exclusion criteria were age $<29$ days or $>18$ years, and anyone who refused to receive a RBC transfusion, for whatever reason. This retrospective observational study was approved by the Ethics Committee of Instituto da Criança. Due to its observational nature, the Committee waived informed consent.

\section{Data collection}

Data collected were age, reason for admission to the PICU, presence of chronic status, presence of organ dysfunction (as defined by Wilkinson et al. ${ }^{(6)}$ ), use of central venous oxygen saturation, arterial lactate, $\mathrm{Hb}$ concentration,
Hct, and therapeutic procedures (mechanical ventilation, use of vasoactive drugs, and renal replacement methods). The analysis of age, reason for admission to the PICU, and presence of chronic status was made with the total number of transfused patients. The analysis of multiple organ dysfunction score (MODS), $\mathrm{SvO}_{2}, \mathrm{SaO}_{2}$, arterial lactate, $\mathrm{Hb}, \mathrm{Hct}$, and therapeutic procedures was made with the total number of transfusional events. MODS and therapeutic procedures data were recorded at the moment of indication of the transfusion. To analyze $\mathrm{SvO}_{2}, \mathrm{SaO}_{2}$, arterial lactate, and pretransfusional $\mathrm{Hb}$ and Hct, we considered the last values observed in laboratory tests within a period of 24 hours until the indication of the transfusion. Each RBC transfusion was considered as a new event, even if the same patient received more than one transfusion. For better comprehension, pretransfusion $\mathrm{Hb}$ concentrations were divided into three groups: $\mathrm{Hb} \leq 7.0 \mathrm{~g} / \mathrm{dL}$, between 7.1 and $9.9 \mathrm{~g} / \mathrm{dL}$, and $\geq 10 \mathrm{~g} / \mathrm{dL}$.

\section{Statistics}

Categorical variables were expressed in absolute and percentage values. To describe continuous variables, medians and interquartile ranges were used (nonnormal distribution). Statistical analyses were performed using the Statistical Package for Social Sciences (SPSS) version 13.0, software. Confidence intervals were calculated using GraphPad StatMate (version 1.01) software.

\section{RESULTS}

\section{Study population}

There were 201 consecutive admissions to the PICU over 6 months. Twenty-three patients $(11 \%$ of the admissions) were not analyzed because their medical records were not available. When admission data of these patients were analyzed, we found that 15 patients likely did not receive the $\mathrm{RBC}$ transfusion. Therefore, we were only able to do follow-up on eight patients.

The total number of patients and the number of transfusional events were analyzed separately. For variables that did not change during the length of stay (i.e., chronic status and age), we analyzed the total number of transfused patients. For the variables that changed during the length of stay (i.e., organ dysfunction, $\mathrm{Hb}$ and $\mathrm{SvO}_{2}$ ), we analyzed the transfusional events.

Four cases (2\%) met exclusion criteria and 74 patients did not receive RBC transfusions and were not included in the study, leaving 100 patients for analysis (50\% of all patients). 
Data at entry into PICU are reported on table 1. Chronic status was present in $84 \%$ of the cases and the most common were oncologic diseases (20 patients), including 15 patients from pediatric surgery (including liver transplantation) and 9 with liver disease without transplant.

\begin{tabular}{lc} 
Table 1. Characteristics of the transfused patients \\
\hline Characteristics & Transfused \\
\hline Patients, $\mathrm{n}$ & 100 \\
Age (months), median (range) & $18(1-208)$ \\
Reason for admission in PICU n (\%) & \\
Respiratory failure & $35(35)$ \\
Postoperative & $17(17)$ \\
Septic shock & $14(14)$ \\
Sepsis/severe sepsis & $9(9)$ \\
Gastrointestinal hemorrhage & $4(4)$ \\
Comma & $3(3)$ \\
Hypertension & $2(2)$ \\
Hemorrhagic shock & $2(2)$ \\
Acute renal failure & $2(2)$ \\
Cerebral vascular accident & $2(2)$ \\
Cardiac arrhythmia & $2(2)$ \\
Apnea/bronchospasm & $2(2)$ \\
\hline
\end{tabular}

PICU: Pediatric Intensive Care Unit.

\section{Transfusional events}

In 100 patients, 173 transfusional events occurred (Figure 1) and, in all but one (172/173), Hb and Hct values were collected prior to the transfusion. Arterial oxygen saturation data was collected in all cases, and in nine patients the result was $<90 \%$. Central venous saturation and arterial lactate values were recorded in $14 \%$ of the cases (24 of 173 transfusional events). For the first parameter, 11 patients had a result lower than $70 \%$, and for the latter, only 3 had values $>20 \mathrm{mg} / \mathrm{dL}$.

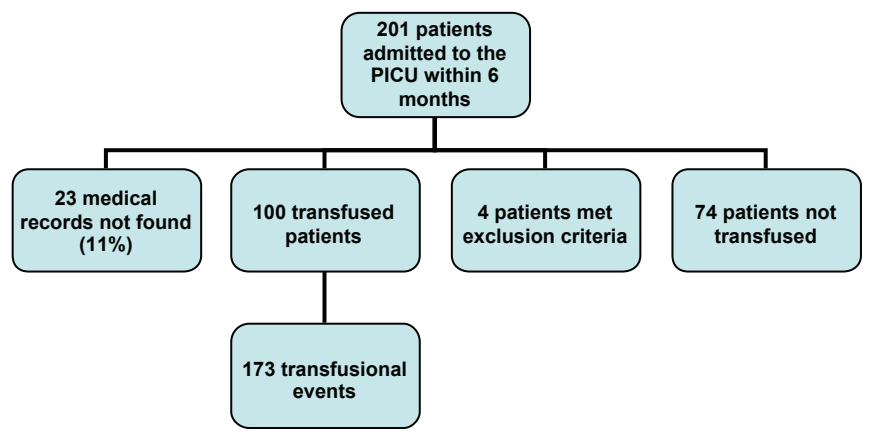

PICU: Pediatric Intensive Care Unit.

Figure 1. Patients admitted to a Brazilian Pediatric Intensive Care Unit from March $1^{\text {st }}$ to September $1^{\text {st }}, 2004$, who formed study population of transfusional practices

In $47 \%$ of the cases ( 80 of 173 events), the patient was transfused during at least two organ failures. Respiratory system failure was present in $36 \%$ of all transfusional events (62 of 173 events) and cardiovascular system failure in $32.9 \%$ (57 of 173 events). In 142 out of 173 transfusional events (82\%), patients were receiving therapeutic procedures, the most common of which was mechanical ventilation (Table 2).

Table 2. Therapeutic procedures in transfusional events of children admitted to a Brazilian Pediatric Intensive Care Unit from March 1st, 2004 to September 1st, 2004

\begin{tabular}{lcc}
\hline Therapeutic procedures & $\mathbf{n}$ & \% (95\% $\mathbf{C l})$ \\
\hline Mechanical ventilation & 122 & $70.5(63.1-77.1)$ \\
Vasoactive drugs & 70 & $40.4(33.0-48.1)$ \\
Peritoneal dialysis & 17 & $9.8(5.8-15.2)$ \\
Hemofiltration & 4 & $2.3(0.6-5.8)$ \\
Hemodialysis & 1 & $0.5(0.01-3.1)$ \\
\hline
\end{tabular}

95\%Cl: $95 \%$ confidence interval.

The overall median pretransfusion value of $\mathrm{Hb}$ was $7.8 \mathrm{~g} / \mathrm{dL}(\mathrm{IQR}=1.5)$. There was no correlation between number of organ dysfunctions and $\mathrm{Hb}$ levels $(\mathrm{R} 2=$ 0.03). Pretransfusion $\mathrm{Hb}$ concentrations are described on table 3.

Table 3. Transfusional events according to the hemoglobin concentration of children admitted to a Brazilian Pediatric Intensive Care Unit from March 1st 2004 to September $1^{\text {st }}, 2004$

\begin{tabular}{lc}
\hline $\mathbf{H b}(\mathbf{g} / \mathbf{d L})$ & Transfusional events, $\mathbf{n}(\%)$ \\
\hline$\leq 7.0$ & $37.0(21.4)$ \\
$7.1-9.9$ & $131.0(75.7)$ \\
$\geq 10$ & $4.0(2.3)$ \\
Not collected & $1.0(0.6)$ \\
\hline Total & $173.0(100)$ \\
\hline
\end{tabular}

\section{DISCUSSION}

$\mathrm{RBC}$ transfusion is common in critically ill patients admitted to intensive care units. The main reason for the indication of a RBC transfusion is $\mathrm{Hb}$ concentration and Htc. No hard data exist in pediatric literature on the risk/benefit ratio of transfusions with $\mathrm{Hb}$ concentrations $>5 \mathrm{~g} / \mathrm{dL}$. A retrospective study reported that many factors other than the $\mathrm{Hb}$ concentration would prompt pediatric intensivists to prescribe a RBC transfusion, such as the age of patient, severity of illness, oxygen delivery, and blood lactate level ${ }^{(7)}$.

One study performed in a PICU analyzed 240 children, and $54.6 \%$ (131 of 240 children) received RBC transfusions ${ }^{(8)}$. Another pediatric study included 985 patients and at least one transfusion was given in 139 children $\left(14 \%\right.$ of the patients) ${ }^{(2)}$. The high number of RBC transfusions in our study can be due to patients with chronic status, oncologic in particular, and, probably, to a higher incidence of anemia and organ dysfunction.

The mean ages of transfused patients in literature were $20.3 \pm 35.6$ months (similar to ours), $6.0 \pm 5.9$ years, and 6.5 years $^{(2,8-9)}$. In 2005, Armano et al. described respiratory failure as the main reason for admission 
in the PICU (57.9\% of the cases) and the second most frequent was elective cardiac surgery $(38.1 \%$ of the cases) ${ }^{(2)}$. Another study, performed by Goodman et al. in 2003, described orthopedic diseases as the main reason for admission (22.1\% of the cases) $)^{(8)}$. Both studies were performed in children. In adults, the most frequent reason for admission was the postoperative period of elective surgeries in $41.9 \%$ of the cases in the study performed by Vincent et al., in $2002^{(10)}$. Reasons for PICU admission change according to local policies and complexities of diseases. In our study, the main reason for admission in the PICU was respiratory failure, followed by postoperative status. The high number of patients with chronic status in our study is not unforeseen and has already been described ${ }^{(11)}$, since the Instituto da Criança is the reference center for treatment of rare and high-complexity diseases in our country.

Patients admitted to intensive care units frequently receive more than one $\mathrm{RBC}$ transfusion during their stay. In the CRITstudy, performed in the United States, $44 \%$ of the patients received one or more $\mathrm{RBC}$ transfusions (average of $4.6 \pm 4.9$ units) ${ }^{(12)}$. In our study, there was 1.73 event per patient.

There are few studies performed in children on this theme (most of the studies were conducted in adults or neonates). A Canadian study performed in adults by Hébert et al., in 1998, reported that most intensivists prescribed $\mathrm{RBC}$ transfusion when the $\mathrm{Hb}$ of the patient was around $9 \mathrm{~g} / \mathrm{dL} \mathrm{L}^{(13)}$.

In 1999, Hébert et al. demonstrated that a restrictive strategy of RBC transfusion is at least as effective as, and possibly superior to, a liberal transfusion strategy in critically ill adult patients ${ }^{(14)}$. A similar study performed in children showed that a restrictive transfusion strategy was safe in pediatric patients whose condition was stable in the ICU, and that such a strategy was as safe as a liberal transfusion strategy ${ }^{(15)}$.

Considering only a restrictive strategy of $\mathrm{RBC}$ transfusion, there is probably still a great number of unnecessary transfusions, but we need to bear in mind that red blood pack transfusions are indicated whenever $\mathrm{Hb}$ is $<10 \mathrm{~g} / \mathrm{dL}$ and a critical patient has a $\mathrm{ScvO}_{2}<70 \%$, as already has been shown in adults ${ }^{(16)}$ and children ${ }^{(17)}$. At the time these data were collected, patients were on continuous $\mathrm{ScvO}_{2}$ monitoring, although these values were not registered on medical records. Consequently, it is very likely that many transfusions have been made based on these criteria.

Values of $\mathrm{SvO}_{2}$ and arterial lactate are valuable markers in assessing cell metabolism as indirect measures of oxygen tissue delivery. Monitoring of $\mathrm{SvO}_{2}$ evaluates the balance between delivery and consumption of oxygen, which is decreased when there is a delivery reduction and/or consumption increase. The presence and persistence of high levels of lactate are related to increases in morbidity and mortality ${ }^{(16,18,19)}$. Cardiac disease and severity of illness on admission to the PICU, as well as the presence of MODS while in PICU, are significant determinants of the first RBC transfusion event $^{(2)}$.

We found that almost half of the transfusional events occurred during two or more organ dysfunctions. Lacroix et al., in 2007, showed that MODS (according to the Prouxl criteria) ${ }^{(20)}$ occurred in $33 \%$ of the patients of the restrictive group and in $34 \%$ of the patients of the liberal group ${ }^{(18)}$. Similar to our findings, the respiratory system was the most common site of dysfunction, in 73 and $78 \%$ of the patients of the two groups, respectively ${ }^{(19)}$.

Comparable values were found by Reis et al., with $83.3 \%$ of transfused patients on mechanicalventilation ${ }^{(9)}$. Hébert et al. showed that RBC transfusion does not influence the duration of mechanical ventilation in adult patients ${ }^{(21)}$.

The major limitation of our study was its retrospective design. Data were collected from medical records and some variables, like central venous oxygen saturation, were not recorded. We chose this design considering that prospective data collection could interfere in current transfusion practice.

\section{CONCLUSION}

RBC transfusions were widely performed in the studied PICU, mostly in a liberal way, i.e., according to $\mathrm{Hb}$ concentration and Htc values. Most PICU patients received therapeutic procedures during their in-hospital stay and mechanical ventilation was the most common one performed. Around half of all transfusional events occurred when there was dysfunction of two or more organs.

\section{REFERENCES}

1. Shander A. Anemia in the critically ill. Crit Care Clin. 2004;20(2):159-78.

2. Armano R, Gauvin F, Ducruet T, Lacroix J. Determinants of red blood cell transfusions in a pediatric critical care unit: a prospective, descriptive epidemiological study. Crit Care Med. 2005;33(11):2637-44.

3. Dudell G, Cornish JD, Bartlett RH. What constitutes adequate oxygenation? Pediatrics. 1990;85(1):39-41.

4. Dennis RC, Clas D, Niehoff JM, Yeston NS. Transfusion therapy. In: Civetta JM, Taylor RW, Kirby RR. Critical Care. $3^{\mathrm{a}}$ ed. Philadelphia: Lippincott-Raven; 1997. p. 639-59.

5. Titlestad K, Georgsen J, Jorgensen J, Kristensen T. Monitoring transfusion practices at two university hospitals. Vox Sang. 2001;80(1):40-7.

6. Wilkinson JD, Pollack MM, Ruttimann UE, Glass NL, Yeh TS. Outcome of pediatric patients with multiple organ system failure. Crit Care Med. 1986;14(4):271-4. 
7. Laverdière $\mathrm{C}$, Gauvin F, Hébert PC, Infante-Rivard C, Hume H, Toledano BJ, et al. Survey on transfusion practices of pediatric intensivists. Pediatr Crit Care Med. 2002;3(4):335-40.

8. Goodman AM, Pollack MM, Patel KM, Luban NL. Pediatric red blood cell transfusions increase resource use. J Pediatr. 2003;142(2):123-7.

9. Reis MA, Felix RJ, Góes PF, Hsin SH, Ventura AM, Barreira ER, et al. Prática transfusional em unidade de terapia intensiva pediátrica de hospital universitário. Rev Bras Ter Intensiva. 2006;(Suppl 1):207-8.

10. Vincent JL, Baron JF, Reinhart K, Gattinoni L, Thijs L, Webb A, et al. Anemia and blood transfusion in critically ill patients. JAMA. 2002;288(12):1499-507.

11. Cardoso MP, Bourguignon DC, Gomes MM, Saldiva PH, Pereira CR, Troster EJ. Comparison between clinical diagnoses and autopsy findings in a pediatric intensive care unit in São Paulo, Brazil. Pediatr Crit Care Med. 2006; $7(5): 423-7$.

12. Corwin HL, Gettinger A, Pearl RG, Fink MP, Levy MM, Abraham E, et al. The CRIT Study: Anemia and blood transfusion in the critically ill--current clinical practice in the United States. Crit Care Med. 2004;32(1):39-52.

13. Hébert PC, Wells G, Martin C, Tweeddale M, Marshall J, Blajchman M, et al. A Canadian survey of transfusion practices in critically ill patients. Transfusion Requirements in Critical Care Investigators and the Canadian Critical Care Trials Group. Crit Care Med. 1998;26(3):482-7.

14. Hébert PC, Wells G, Blajchman MA, Marshall J, Martin C, Pagliarello G, et al. A multicenter, randomized, controlled clinical trial of transfusion requirements in critical care. Transfusion Requirements in Critical Care Investigators, Canadian Critical Care Trials Group. N Engl J Med. 1999;340(6):409-17.
15. Lacroix J, Hébert PC, Hutchison JS, Hume HA, Tucci M, Ducruet $T$, Gauvin F, Collet JP, Toledano BJ, Robillard P, Joffe A, Biarent D, Meert K, Peters MJ; TRIPICU Investigators; Canadian Critical Care Trials Group; Pediatric Acute Lung Injury and Sepsis Investigators Network. Transfusion strategies for patients in pediatric intensive care units. N Engl J Med. 2007;356(16):1609-19.

16. Rivers E, Nguyen B, Havstad S, Ressler J, Muzzin A, Knoblich B, Peterson E, Tomlanovich M; Early Goal-Directed Therapy Collaborative Group. Early goaldirected therapy in the treatment of severe sepsis and septic shock. N Engl J Med. 2001;345(19):1368-77.

17. de Oliveira CF, de Oliveira DS, Gottschald AF, Moura JD, Costa GA, Ventura AC, et al. ACCM/PALS haemodynamic support guidelines for paediatric septic shock: an outcomes comparison with and without monitoring central venous oxygen saturation. Intensive Care Med. 2008;34(6):1065-75.

18. Bakker J. Blood lactate levels. Curr Opin Crit Care. 1999;5(3):234.

19. Mazza BF, Machado FR, Mazza DD, Hassmann V. Evaluation of blood transfusion effects on mixed venous oxygen saturation and lactate levels in patients with SIRS/sepsis. Clinics (Sao Paulo). 2005;60(4):311-6.

20. Proulx F, Fayon M, Farrell CA, Lacroix J, Gauthier M. Epidemiology of sepsis and multiple organ dysfunction syndrome in children. Chest. 1996;109(4):1033-7.

21. Hébert PC, Blajchman MA, Cook DJ, Yetisir E, Wells G, Marshall J, Schweitzer I; Transfusion Requirements in Critical Care Investigators for the Canadian Critical Care Trials Group. Do blood transfusions improve outcomes related to mechanical ventilation? Chest. 2001;119(6):1850-7. 